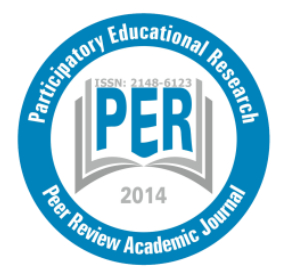

Participatory Educational Research (PER)

Vol. 7(2), pp. 33-46, August 2020

Available online at http://www.perjournal.com

ISSN: 2148-6123

http://dx.doi.org/10.17275/per.20.18.7.2

\title{
Effectiveness of The Big Math for Little Kids Program on the Early Mathematics Skills of Preschool Children with a Bilingual Group
}

\begin{tabular}{|c|c|}
\hline \multicolumn{2}{|c|}{$\begin{array}{c}\text { Özlem Altındağ Kumaş* } \\
\text { Special Education Department, Dicle University Ziya Gökalp Education Faculty, Diyarbakır, } \\
\text { Turkey, ORCID: 0000-0002-6104-2381 }\end{array}$} \\
\hline Article history & The objective of this study is to explore the effect of the Big Math for \\
\hline $\begin{array}{l}\text { Received: } \\
\text { 23.01.2020 }\end{array}$ & \\
\hline $\begin{array}{l}\text { Received in revised form: } \\
09.03 .2020\end{array}$ & $\begin{array}{l}\text { with pre-test/post-test with control group was employed. A total of } 60 \\
\text { children from Diyarbakir were included in the research sample. Of these, } \\
30 \text { were assigned to the experimental group and } 30 \text { to the control group. }\end{array}$ \\
\hline $\begin{array}{l}\text { Accepted: } \\
10.03 .2020\end{array}$ & $\begin{array}{l}\text { In the study pretest-posttest with control group experimental model was } \\
\text { used. The data of the study were collected through the Tests of Early }\end{array}$ \\
\hline Key w & Language Development Test (TELD-3) to determine children with \\
\hline $\begin{array}{l}\text { Early mathematics, } \\
\text { bilingualism, preschool period }\end{array}$ & $\begin{array}{l}\text { adequate language skills of their own age group, and Test of Early } \\
\text { Mathematical Ability (TEMA-3) to assess early mathematical } \\
\text { development of children. BMLK program were applied to the } \\
\text { experimental group for } 12 \text { weeks by the researcher. The main themes of } \\
\text { the four units are numbers, shapes, patterns and measurement skills. After } \\
\text { the experiment, TEMA-3 test and TELD test were applied to the } \\
\text { experimental and control groups as post-test. The obtained data were } \\
\text { analyzed by using Mann-Whitney U and Wilcoxon tests. As a result of } \\
\text { the study, it was identified that the Big Math for Little Kids Program has } \\
\text { a statistically significant effect on early mathematical skills of children in } \\
\text { favor of the experimental group when compared to the control group. }\end{array}$ \\
\hline
\end{tabular}

\section{Introduction}

Language is an important instrument that meets the communication needs of the members of a society and relays the beliefs and values, which are elements of the cultural heritage of a society, to future generations. The surrounding environment plays an important role in a child's language acquisition process. Children acquire their mother tongue first. There are similarities among the stages of all children's mother tongue acquisition (Bloom, 1970; Halliday, 1975; Warren and Yoder, 1998; Wilcox and Shannon, 1998). Even though adults of different cultures adopt different strategies based on their own cultures to facilitate lingual development, they use language to communicate with their children and support and guide language acquisition (Chiocca, 1998; Wilcox and Shannon, 1998). It is an extremely complex task for a child to learn the "mother tongue", which is the language a person uses, masters, and expresses himself the best in.

\footnotetext{
* Correspondency: ozlemmaltindag@ gmail.com
} 
While learning the mother tongue itself a complex and difficult task, children who have to learn a second language face an even bigger task. Bilingualism can be defined in two different ways according to linguists. While some linguists consider "bilingualism" as the command of a child or an adult of a language in terms of listening, speaking, reading-writing, and comprehension at the same degree of his mother tongue (Clark, 2002; McLaughlin et al., 1995) other linguists claim that having a certain command of both languages is sufficient enough for a person to be "bilingual" (Watson, 1995). With its acknowledged definition today, bilingualism is the constant daily exposure of a person to a language other than his mother tongue (ERG, 2010). Bilingualism may arise due to various reasons such as having parents that speak different mother tongues, speaking a different language than the one the general society speaks, and living in a different country (Yazgan, 2017).

It is pointed out that if bilingualism is supported properly, the development of a bilingual child can progress as normal as a monolingual child, otherwise the bilingual child will lag their peers (Cummins, 2003). Cummins stated that the level of development of the mother tongue of a child is a strong determinant of second language development, the use of mother tongue at schools has a positive impact not only on the development on the mother tongue but also on the linguistic and educational development of the child, and rejecting a child's language in school means rejecting the child himself. It is also essential to develop a child's skills to use a language effectively, which can have a positive impact on that child's academic performance, in an appropriate teaching-learning environment during the pre-school period-a time during which language development is of critical importance (Koşan, 2015).

In terms of bilingualism in Turkey, there is a significant population in the Eastern and Southeastern Anatolia Regions belonging to a different ethnic group speaking another language. The development level of all provinces in this region, excluding Gaziantep, is lower than the national average (TSI, 2015). Since they have non-Turkish speaking parents, the majority of children in the Southeastern Anatolia Region start learning Turkish in school, not in their families. In this region, the most commonly spoken languages are Kurdish and Arabic, respectively (Buran, 2009). These children, whose mother tongue is not Turkish, attend the same educational programs as native Turkish speaking children. The Turkish educational system does not have intervention programs or additional support for children who do not speak Turkish, or who speak it inadequately. This situation leads to an unlevel playing field and the gap of academic performance between bilingual and non-bilingual children is widening (Myers, 1992). Not having full command over the Turkish language, these children are unable to fully understand questions in exams, thus failing (Y1lmaz, 2014).

Some studies show that bilingual children of early childhood experience difficulties in mathematics the most, among all academic fields (Galindo and Sheldon, 2011; Lee and Bowen, 2006; Tsneg, 2002). Mathematical skills acquired during early childhood play a very important role in improving a child's readiness for school and future academic skills (Buldu, 2016; Erdoğan, 2006; Unutkan, 2006; Uyanık and Kandır, 2010). It is this period where the foundation of mathematical knowledge is laid that will help a child to understand mathematics and other academic fields. That is, this fundamental knowledge increases success by facilitating a child's future academic life, helps the child to acquire problemsolving skills and to become a productive and efficient member to the society (Aunio, Hautamaki, Sajaniemi and Van Luit, 2009). Many studies suggest that early mathematical skills highly predict a child's future mathematical performance and success in other academic fields (Aunio et al., 2009; Duncan et al., 2007). Not fearing mathematics; on the contrary, loving it, being excited about learning it, and having a positive attitude towards it at primary 
school where they are taught it in a formal fashion have a direct positive impact on a child's related experiences during his early childhood (Williams and Coles, 2007).

High-quality pre-school programs would play an important role in eliminating or narrowing the gap between bilingual children and their peers in Turkey. There are many studies proving that such programs eliminate the gaps on school readiness, or socioeconomic or ethnic gaps (Campbell and Ramey, 1994; DeLoach 2012; Kağıtçıbaş1, Sunar and Bekman, 2001; Opel, Zaman, Khanom and Aboud, 2012; Presser, Clements, Ginsburg and Ertle, 2012). It is noted that children, who complete such programs, are academically more successful, work in higher-quality jobs, and benefit from healthcare systems more effectively. From this perspective, it is important that children are supported with necessary mathematical skills in early childhood and programs are designed accordingly. Despite this fact, it is known that preschool education programs do not offer quality and adequate training on developing early mathematics skills which results in an increased possibility for children to encounter difficulties in mathematics (DeLoach, 2012).

It is particularly important to support bilingual children in early childhood to help them acquire mathematical skills. The studies reveal that bilingual children can close the performance gap between their peers when they make use of mathematical practices in the pre-school period (Ginsburg, Greenes and Balfanz, 2003; McCartney and Taylor, 2009). It is also a known fact that intervention programs that are designed by taking into consideration the characteristics of children, have a significantly positive impact on the mathematical skills of these children (Ayvac1, 2010; Clements and Sarama, 2008; Orcan, 2013). This is the reason why effective mathematical programs that support the mathematical development of bilingual children are needed. However, there is no such program in place in Turkey that can help bilingual children to develop mathematical skills in early childhood.

Having said that it is notable that a fair number of developed countries have intervention programs for bilingual children embedded in their mathematics curricula. One of these mathematics intervention programs is the one applied for bilingual children called Big Math for Little Kids (BMLK) (Ginsburg, Greenes and Balfanz, 2003). Researchers who developed this program point out that learning mathematics is inevitably correlated with the development of language and communication skills. According to the researchers, mathematics requires using specific (e.g. rhombohedron) and general vocabulary, understanding symbols, communication, and proving. Thereupon, such an experience improves children's language and literacy level. The researchers also pinpoint that the language of mathematics is a brand new one not only for bilingual but for all children and learning this language could considerably improve the language skills of bilingual children (Ginsburg, Greenes and Balfanz, 2003). Thence, it is considered that the problems bilingual students have in terms of mathematical skills in early childhood can be reduced by implementing such educational programs. Accordingly, this study aims to explore the effectiveness of the Big Math for Little Kids program on supporting the mathematical skills of bilingual children in kindergarten in the early childhood period.

\section{Methodology}

The study group consisted of 60 children-28 girls and 32 boys-with a mean age of 64 months, who are attending independent kindergartens affiliated to the Ministry of National Education in Diyarbakir city center in the school year of 2017-2018. The criteria below were taken into consideration during the selection process: 
- Children who speak a language other than Turkish at home,

- Have Turkish language proficiency,

- Are in the low socioeconomic level,

- Are said to have an average success level by their teachers, who do not have any medical diagnosis,

- Are between the ages of 60 to 72 months took part in the study.

Students who participated in the study were selected among the ones attending one of the two independent kindergartens in the Yenişehir district of Diyarbakır province. Both the experimental and control groups had 30 students (14 girls and 16 boys).

\section{Data Collection Tools}

The study employed the Test of Early Mathematics Ability (TEMA-3) to assess children's mathematical development and the Test of Early Turkish Language Development (TELD) to assess children with adequate receptive Turkish language proficiency.

\section{TELD (Test of Early Turkish Language Development)}

TELD is a norm-based test that was developed by Hresko, Reid, and Hammill (1999) in the US to measure the receptive and expressive language skills of children of ages 3 years 0 months through 7 years 11 months (Güven, 2009). This test is widely used to identify children with language disorders in the early childhood period, to show the weaknesses and strengths of their language development, and to provide information and explore the process of development. For ease of use, it was named TELD (Test of Early Turkish Language Development) in Turkey (Güven, 2009).

Covering three of the five fundamental components of language, TELD measures semantics, syntax, and morphology through sub-tests and questions. TELD includes two sub-tests, namely for the receptive and expressive languages. The A Form for Receptive Language Subtest consists of 24 questions measuring semantics, the B Form for Receptive Language Subtest consists of 25 questions measuring semantics, the A Form for Receptive Language Subtest consists of 13 questions measuring syntax/morphology, and the B Form for Receptive Language Sub-test consists of 12 questions measuring syntax/morphology. The A Form for Expressive Language Sub-test consists of 22 questions measuring semantics, the B Form for Expressive Language Sub-test consists of 24 questions measuring semantics, the A Form for Expressive Language Sub-test consists of 17 questions measuring syntax/morphology, and the B Form for Expressive Language Sub-test consists of 15 questions measuring syntax/morphology.

Some of these questions use the method of showing or describing pictures, and other questions use the method of fulfilling verbal instructions and verbally answering questions. Record forms for examiners consist of 7 sections. The information on the front page of these forms must be fully completed. In the reliability study of the TELD, internal consistency coefficients of the test were measured for different age groups and for different demographic sub-groups and for both forms and sub-tests were found to be ranging from .86 and .98 . These figures show that the test has a very high internal consistency. In the validity study, the internal correlation of the scores obtained from the subtests was found to be between .87 and .91 for both forms used for the whole sample group. These high figures show that the test has associated components that measure the same structure (Güven, 2009). The TELD is generally administered in 15 to 40 minutes based on the child's age and skills. 
The instructions and scoring principles were developed in a simple way to facilitate implementation and scoring. For each question in the form, the score is a " 1 " for correct, if the criteria are met, or a " 0 " (or 'failed') for incorrect provided the criteria are not met. Then, the raw scores from the Receiving Language and Expression Language Sub-tests are added up and written in the Raw Score column in the Section 2: TELD Scores and Results section on the first page (front page) of the Record Form. The raw scores are converted to standard scores by using the tables on the back of the Examiner's Manual, and the age equivalent, percentile rank. The verbal language composite score is calculated by totaling the standard scores of Receiving and Expressive Language Sub-tests. This composite score offers information on a child's verbal language skills (Güven, 2009).

\section{TEMA-3}

TEMA (Test of Early Mathematics Ability) was developed by Ginsburg and Baroody in 1983 with an aim to measure the mathematics performance of children between the ages of 3 and 8-11. TEMA was reviewed in 1990 and published under the name 'Test of Early Mathematics Ability-2: TEMA-2'. The validity and reliability study of TEMA-2 in Turkey was conducted by Güven (1997) it was found to be a valid and reliable scale. Reviewed once more, the TEMA-2 was developed into TEMA-3 (Ginsburg and Baroody, 2003). The test involving seventy-two questions measures informal aspects of mathematics such as more-less, counting, and informal calculation, as well as formal aspects of it such as numbers, relations between numbers, calculation, and decimals (Erdoğan, 2006). Consisting of two parallel forms, TEMA-3 uses pictures, mathematical symbols, countable small items for materials.

The test is administered individually by calculating the chronological age and starting with the question corresponding to that age. The test is terminated when the child fails to answer five consequent questions, otherwise each question is marked as either correct or incorrect, and the number of correct answers totaled up to the raw score. And the raw scores are converted to math ability scores. By taking into consideration the child's chronological age and his raw score, his math score is determined from the score chart. The increase in the math score points to an improvement in a child's mathematical ability (Ginsburg and Baroody, 2003). TEMA-3's standardization and adaptation efforts into Turkish were conducted by Erdoğan (2006). In terms of the test-retest reliability, Erdoğan's analyses pointed out the Pearson correlation coefficient to be .90 for Form A and .86 for Form B. The study calculated the internal consistency coefficient on test validity and the KR-20 value was found to be .92 for Form A, and .93 for Form B. As a result, the test was found to have high validity and reliability in terms of measuring the mathematical skills of Turkish children between the ages of 60 to 72 months (Erdoğan, 2006). These results are in parallel with the results of the original test (Form A .94, Form B .96) (Ginsburg and Baroody, 2003).

\section{The Intervention Program to be Implemented}

The Big Math for Little Kids Program is a research-based, comprehensive, planned and fun math program developed by Ginsburg et al. (2003). This program is based on supporting the mathematical development of children aged 61 to 72 months during the preschool period. The program aims to benefit from the connections between children's available knowledge, their interests, and their skills and the mathematical thoughts involved in their daily experiences and other activities. This program offers encouraging opportunities for children to come up with mathematical discoveries in an environment supported by free and rich stimuli and aims to support children to reason and discuss their own discoveries (Ginsburg et al., 2003). 
This educational program also has an objective to improve children's use of the language of mathematics. The language of mathematics include not only the use of mathematical terminology (numbers, shapes) and symbols $(+,=)$ but also the ability to use the language about location (adjacent, between), unity/integrity (together, all together, all), estimation (likely, unlikely) and checking (incorrect, check the answer, correct). By improving the language of mathematics, the program also aims to strengthen children's discussion and reasoning skills (Greenes, Ginsburg and Balfanz, 2004; Morgenlander and Manlapig, 2006).

The curriculum covers activities in six units: number, shape, patterns and logic, measurement, number operations, and space. Story books were developed for each of these units. The stories were designed to help children to understand deeper and greater ideas associated with the language of mathematics. In addition, children are offered the possibility to tell the stories to each other, complete the gaps in the pictures, and take the book home to read it with their families (Morgenlander and Manlapig, 2006; Greenes, Ginsburg and Balfanz, 2004).

\section{Data Collection}

Before the data collection phase, the researcher held a briefing with the classroom teacher of the experimental group and the principle informing them about the objective, content, and implementation of the Big Math for Little Kids Program. In this briefing, the Big Math for Little Kids Program was introduced, and information was provided on the impact of this program on children's mathematical development and activities covered within the program were shared.

\section{Administration of the Pre-tests}

The study measured the receptive language skills of children first. Based on the thought that children, who do not have full command of Turkish, would not be able fully benefit from the educational program and have difficulty understanding the test instructions, children, who do not own the receptive language skills of their peers were excluded from the study.

The TELD (Test of Early Turkish Language Development) was employed to identify the children with adequate Turkish receptive language skills. And the Test of Early Mathematics Ability (TEMA-3) was employed to identify the early mathematical skills of children. A comfortable seating and a quiet classroom arrangement were ensured to administer the test in the school in an appropriate way. The tests took approximately 20 to 30 minutes to administer. At the beginning of each session, a short conversation of few minutes was held to allow the child to get used to the environment and the evaluator. The evaluation began when the child was ready to start.

\section{Implementation of the Big Math for Little Kids Educational Program}

After the administration of the pre-tests, 35 activities in the Unit 1, Unit 2, and Unit 3 of the Big Math for Little Kids Educational Program were carried out with the experimental group. The educational program was implemented by the researcher for 40 minutes to one and a half hours a day two days a week for 12 weeks. The Big Math for Little Kids Educational Program was not implemented for the children in the control group, instead they continued the Pre-School Educational Program for Children 36 to 72 Months of the Ministry of National Education. The researcher arranged the environment properly before the mathematical education to be applied to the experimental group for each activity. For the practice, chairs 
and desks were arranged accordingly or pulled aside to create an empty space. The researcher brought materials to the class beforehand according to the number of children. Children were informed beforehand that activities would place and games would be played.

The first unit of the Big Math for Little Kids educational program entitled "What are Numbers?" includes activities that improve children's skills to say the counting sequence, to use a number to tell "how many" (cardinality), and to use ordinal numbers to identify positions in a line (for example, which object is the first, second, third, ..... tenth, last). In this unit, children learn concepts and skills about counting sequence, counting numbers (being able to tell how many), and ordinal numbers (being able to count to identify which one).

The activities in the second unit named "the Shapes of Things" consists of activities about names and attributes of two- and three-dimensional shapes as well as the concept of symmetry. In this unit, children learn about the different dimensions and positions of circles, triangles, squares, rectangles, pentagons, and hexagons. They also count and compare the sides and vertices of these shapes. Children look for objects in the classroom to find examples of sphere, cube, rectangular prism, or cylinder. The activities in this unit include building twodimensional shapes and two-dimensional towers.

The focal point of the third unit titled "Patterns" are repeating and growing patterns. Children discover patterns involving shape, size, color, numbers, letters, rhythm, or stage, repeating patterns such as $\mathrm{ABAB}$, or growing patterns such as 2, 4, 6, 8. Children acquire skills such as copying, completing, continuing (expanding), identifying patterns, or predicting the next pattern. This unit also includes activities to teach which option is the best to solve a problem and how to use a clue in doing so. Thusly, the aim of this unit is to develop children's skills to logically reason. The activities in this unit call for the use of skills to recognize shapes and to count. In this unit, children investigate the concepts of length, weight, capacity, temperature, time and money. Activities in this unit are comprised of measuring, comparing and ordering objects by length and weight.

\section{Data analysis}

The data collected within the framework of the study was analyzed using the IBM SPPS 22 package program. With an aim to come up with answers to the research questions in line with the objectives of the study, firstly, it was examined whether the data presented normal distribution. The coefficient of skewness of measurements were found to be between .3 and -4.4 while the coefficient of kurtosis to range between -7.0 and -8.3 . Not all of the measurements showed normal distribution $(\mathrm{K}-\mathrm{S}(\mathrm{z})=0.00 ; \mathrm{p}<.00)$ according to the Kolmogorov-Smirnov test (Pallant, 2015).

The Wilcoxon signed-rank test (rank sum) was employed to compare TEMA-3 pre- and posttest average scores among children in the experimental and control groups since the scores did not show a normal distribution. The Mann Whitney $U$ test was employed to compare the preand post-test average scores of the children in the experimental and control groups from TEMA-3 and TELD. The effect size for the Mann Whitney U and Wilcoxon Signed-Rank Test was calculated by dividing the $z$ value by the square root of the sample size (Pallant, 2016). According to Cohen's criteria .1 indicates a small, .3 indicates a medium, and .7 indicates a large effect size (Cohen, 1998). 


\section{Findings}

This study was carried out to explore the effectiveness of the Big Math for Little Kids Educational Program on the mathematical skills development of bilingual children who attend kindergarten. Any significant difference between the pre- and post-test average scores for TELD and TEMA-3 of children in experimental and control groups was inquired into using the Mann Whitney U-Test. The average scores, standard deviations, mean ranks, rank sums, $\mathrm{U}$ and $\mathrm{p}$ values and effect sizes of the groups in these tests are presented in Tables 1 and 2, accordingly.

Any significant difference between TEMA-3 pre- and post-test average scores among children in the experimental and control groups was investigated using the Wilcoxon signedrank test. Mean ranks, mean sums, $z$ and $p$ values, and effect sizes of children in the experimental and control groups for TEMA-3 and TELD are presented in the Tables $3-8$ below, respectively.

Table 1. Mann Whitney U-Test Results on TELD Scores of Children Participated in the Study

\begin{tabular}{lcccccccc}
\hline Group & $\mathbf{N}$ & $\overline{\boldsymbol{X}}$ & $\boldsymbol{S S}$ & $\begin{array}{l}\text { Mean } \\
\text { Rank }\end{array}$ & $\begin{array}{l}\text { Mean } \\
\text { Sum }\end{array}$ & $\boldsymbol{U}$ & $\boldsymbol{p}$ & Effect \\
\hline $\begin{array}{c}\text { Experimental } \\
\text { Control }\end{array}$ & 30 & 98.55 & 6.93 & 22.85 & 490 & 185 & .68 & .03 \\
\hline
\end{tabular}

Table 1 shows that TELD pre-test scores of experimental and control group children are close. Similarly, the result of the Mann Whitney U-Test showed no significant difference between average TELD pre-test scores of experimental and control groups $(U=185, p=.68)$. These results show that TELD pre-test scores of children are independent of their groups and similar with respect to the receptive language skills of groups.

Table 2. Mann Whitney U-Test Results on TEMA-3 Scores of Children Participated in the Study

\begin{tabular}{ccccccccr}
\hline Group & $\mathbf{N}$ & $\overline{\boldsymbol{X}}$ & $\boldsymbol{S S}$ & $\begin{array}{c}\text { Mean } \\
\text { Rank }\end{array}$ & $\begin{array}{l}\text { Mean } \\
\text { Sum }\end{array}$ & $\boldsymbol{U}$ & $\boldsymbol{p}$ & Effect \\
\hline Experiment & 30 & 80.95 & 7.65 & 21.70 & 435 & 178 & .82 & .11 \\
Control & 30 & 80.25 & 7.72 & 19.98 & 396 & & & \\
\hline
\end{tabular}

Table 2 shows that TEMA-3 pre-test scores of experimental and control group children are close. Similarly, the result of the Mann Whitney U-Test showed no significant difference between the average TEMA-3 pre-test scores of experimental and control groups $(U=178$, $p=.82$ ). These results show that TEMA-3 pre-test scores of children are independent of their groups and similar in terms of early mathematical skills of groups. 
Table 3. Mann Whitney U-Test Analysis Results for TEMA-3 Post-test Scores of Children Participated in the Study

\begin{tabular}{ccccccccr}
\hline Group & $\mathbf{N}$ & $\overline{\boldsymbol{X}}$ & $\boldsymbol{S S}$ & $\begin{array}{l}\text { Mean } \\
\text { Rank }\end{array}$ & $\begin{array}{l}\text { Sum of } \\
\text { Ranks }\end{array}$ & $\boldsymbol{U}$ & $\boldsymbol{p}$ & Effect \\
\hline Experimental & 30 & 94.85 & 2.39 & 28.13 & 580.50 & 28.50 & .000 & .69 \\
Control & 30 & 81.25 & 6.79 & 11.87 & 236.50 & & & \\
\hline
\end{tabular}

The analysis results in Table 3 show significant differences between TEMA-3 scores $(\mathrm{U}=28.50, \mathrm{p}<.001)$. TEMA-3 average scores and mean ranks of the experimental group are higher than of the control group. It is a striking finding that the effect size between groups is large (.69).

Table 4. Comparison of TEMA-3 Pre- and Post-test Average Scores of the Experimental Group Children Participated in the Study

\begin{tabular}{|c|c|c|c|c|c|c|}
\hline PostTest-Pre Test & $\mathbf{N}$ & Mean Rank & $\begin{array}{ll}\text { Sum of } \\
\text { Ranks }\end{array}$ & $z$ & $p$ & Effect \\
\hline Negative Ranks & 1 & 1 & 1 & & & \\
\hline Positive Ranks & 25 & 7 & 77 & -3.00 & .00 & .77 \\
\hline Ties & 4 & & & & & \\
\hline
\end{tabular}

According to the results of the Wilcoxon signed-rank test in Table 4, TEMA-3 scores of children in the experimental group rose significantly $(z=-3.00 ., p=.00)$ after receiving the educational program. The mean rank of experimental group children rose to 7 compared to 1 before the intervention. It is also evident that the effect size was large ( $r=.77)$. All these findings support the idea that the Big Math for Little Kids educational program has a positive impact on early mathematical skills of pre-school bilingual children.

Table 5. Comparison of TEMA-3 Pre- and Post-test Average Scores of the Control Group Children Participated in the Study

\begin{tabular}{lllccccc}
\hline Post Test - Pre Test & N & Mean Rank & $\begin{array}{l}\text { Sum } \\
\text { Ranks }\end{array}$ & of & $z$ & $p$ & Effect \\
\hline Negative Ranks & 11 & 3.9 & 14 & & & \\
$\begin{array}{l}\text { Positive Ranks } \\
\text { Ties }\end{array}$ & 9 & 3.5 & 7 & -.73 & .46 & .18 \\
\hline
\end{tabular}

According to the results of the Wilcoxon signed-rank test in Table 5, there was no significant difference $(z=-.73, p>.46)$ between TEMA-3 pre- and post-test scores of children in the control group, who did not take part in the educational program.

Table 6. Mann Whitney U-Test Analysis Results for TELD Post-test Scores of Children Participated in the Study

\begin{tabular}{ccccccccr}
\hline Group & $\mathbf{N}$ & $\overline{\boldsymbol{X}}$ & $\boldsymbol{S S}$ & $\begin{array}{l}\text { Mean } \\
\text { Rank }\end{array}$ & $\begin{array}{l}\text { Mean } \\
\text { Sum }\end{array}$ & $\boldsymbol{U}$ & $\boldsymbol{p}$ & Effect \\
\hline Experimental & 30 & 99.55 & 6.93 & 22.85 & 493 & 186 & .68 & .03 \\
$\quad$ Control & 30 & 97.65 & 6.85 & 21.15 & 424 & 186 \\
\hline
\end{tabular}

Table 6 shows that TELD post-test scores of experimental and control group children are close. Likewise, the result of the Mann Whitney U-Test displayed no significant difference 
between average TELD post-test scores of experimental and control groups $(U=186, p=.68)$.

\section{Discussion and Conclusion}

As to data collection tools, this study adopted the TEMA-3 test for assessing early mathematical skills, and the TELD for assessing receptive language skills. The results listed in Table 1 show children to have average receptive language skills. Cummins argued that there is a difference between social and academic language acquisition (Cummins, 1991). According to Cummins, basic interpersonal communication skills are communicational skills required to listen and speak in social situations. This concept refers to the ability to engage in small talk, in the market or on the street for instance, that can be acquired in a short period. Some individuals develop contextual cues (including gestures), which usually take place in face-to-face situations. Thereupon, such a process does not need challenging cognitive tasks or require proficiency in a language (Baker, 2011). Children develop daily speaking skills in the second language in two years, at about the age of 5 , same as their peers as they get intensively exposed to this language at school, or in their surroundings (Cummins, 2001). Children in this study are intensively exposed to Turkish through the TV or their surroundings since they live in a central district. This could be the reason why the children in the experimental group have average language skills.

As the second result of the study, there was no statistically significant difference between TEMA-3 pre-test average scores of the experimental group and the control group. Notwithstanding, a statistically significant difference was detected in favor of the experimental group between the post-test scores of the experimental group and the post-test average scores of the control group. This result is found to be consistent with the relevant literature (Blevins-Knabe and Musum-Miller, 1996; Matthews and Ewen, 2006; Young and Loveridge, 2004). These said studies found out that quality mathematical intervention programs have an impact on early mathematical skills of bilingual children.

Owing to the fact that the BMLK program is child-centered; attracting children's attention, offering them activities to investigate the basics of mathematics in depth, systematically, and sequentially, and due to the fact that it is play-based, children in the experimental group scored higher in the early mathematical skills test. Even though the Turkey preschool program is game based, it does not cover early mathematical skills sufficiently. In addition, early mathematical skills integrated in the program are at a very basic level, and not the focal point of any activity. The literature suggests that child-centered, interesting, challenging, systematic, ordered, and play-based activities with a main theme of early mathematical skills play an important role in improving the mathematical skills of especially bilingual children (Skwarchuk, 2009). It is thought that these are the reasons why the control group children performed relatively worse than the experimental group children.

One of the reasons behind the success of the children in the experimental group is the fact that the BMLK program also allows families in the education processes through activities such as "the family letters", "take home game", and "take home story book." The studies put forward that involvement of families in school activities of their children, regardless of race/ethnicity, improve their academic performance, positive attitude towards school, and school attendance (Galindo and Sheldon, 2011; Tsneg, 2002). In their study, Galindo and Sheldon (2011) diagnosed a strong connection between families' participation in school activities and pre-school mathematical performance of children.

Another possible reason why the BMLK intervention has an impact on early mathematical 
development of bilingual children is that the language of mathematics is highlighted as a part of the program. It is known that especially bilingual children have a difficult time explaining their mathematical thoughts and clearly articulating their mathematical skills (Tsneg, 2002). It is underlined that teacher's frequency to use the language of mathematics in classrooms is related to children's mathematical knowledge in later years (Klibanoff, Levine, Huttenlocher, Vasilyeva and Hedges, 2006). It is an effective teaching practice in introducing mathematics using books (Hong, 1999). Whitin and Whitin (1996) announced that children are capable of establishing a relationship between the language of mathematics and their own worlds through story books that incorporate mathematical concepts. All activities in the BMLK program highlight the language of mathematics and have story books for every key concept in each unit. These books are read interactively with children and black and white copies of these books are handed out to children to share with their families at home. Thereby, it is considered that the results of bilingual children, who took part in this program, are achieved since the BMLK program puts an emphasis on the language of mathematics.

The study clearly demonstrates the need for bilingual children to be supported in early mathematical skills. To that end, it is recommended for teachers to be informed about early mathematical skills and supported to translate these interventions to into practice. Pre-school teachers should be supported in having more command of the mathematical concepts and skills through in-service trainings, and on how to plan and measure mathematical activities. High-quality pre-school programs would play an important role in eliminating or narrowing the gap between bilingual children and their peers in Turkey. There are many studies exhibiting that such programs eliminate the gaps on school readiness, or socioeconomic or ethnic gaps (Kağıtçıbaşı, Sunar and Bekman, 2001; Opel, Zaman, Khanom and Aboud, 2012; Presser, Clements, Ginsburg and Ertle, 2012). It is recommended to cooperate with the Directorate-General for Pre-School Education of the Ministry of National Education to assure the inclusion of the principles and activities of the Big Math for Little Kids educational program in the national curriculum.

There are some limitations to bear in mind while interpreting the results of this study. One of them is the limited number of children included in this study. To be able to generalize the findings, similar studies should be carried out with larger groups. The second one is the fact that the research sample is a small group and it reflects the characteristics of a particular local area. For this reason, it would yield more reliable results to conduct studies with larger samples from a variety of regions.

\section{References}

Aunio, P. Hautamäki, J., Heiskari, P., \& Van Luit, J. E. H. (2006). The Early Numeracy Test in Finnish: Children's norms. Scandinavian Journal of Psychology, 47, 5, 369-378.

Ayvaci, H. Ş. (2010). Okul öncesi dönem çocuklarının bilimsel süreç becerilerini kullanma yeterliliklerini geliştirmeye yönelik pilot bir çalışma [A Pilot Survey to Improve the Use of Scientific Process Skills of Kindergarten Children]. Necatibey Eğitim Fakültesi Elektronik Fen ve Matematik Ĕ̈itimi Dergisi, 4(2), 1-24.

Baker, C. (2011). Foundations of bilingual education and bilingualism. Clevedon: Multilingual matters.

Blevins-Knabe, B., \& Musun-Miller, L. (1996). Number use at home by children and their parents and its relationship to early mathematical performance. Early Development and Parenting: An International Journal of Research and Practice, 5(1), 35-45. 
Buldu, M. (2012). Okul öncesi dönemde matematiksel kavram gelişimi [Matematics in Preschool]. Berrin Akman (Editör) Okulöncesi matematik eğitimi, (ss. 28-45). Ankara: Pegem Yayınevi.

Campbell, F. A., \& Ramey, C. T. (1994). Effects of early intervention on intellectual and academic achievement: a follow-up study of children from low-income families. Child development, 65(2), 684-698.

Chiocca, E. M. (1998). Language development in bilingual children. Pediatric nursing, 24(1), 43.

Clark, B. (2000). First and second language acquisition in early childhood. Proceedings of the Lilian Katz Symposium. Issues in Early Childhood Education: Curriculum, Teacher Education, and Dissemination of Information, 181-188.

Clements, D. H., \& Sarama, J. (2009). Learning trajectories in early mathematics-sequences of acquisition and teaching. Encyclopedia of language and literacy development, 1-7.

Cohen, J. (1988). Statistical power analysis for the behavioral sciences (2nd ed.). Hillsdale, NJ: Erlbaum.

Cummins, J. (1991). Interdependence of first-and second-language proficiency in bilingual children. Language processing in bilingual children, 70-89.

Cummins, J. (2009). Multilingualism in the English-language classroom: Pedagogical considerations. TESOL quarterly, 43(2), 317-321.

Cummins, J. (2003). Bilingual Education: Basic principles. In J. Dewaele, A. Housen and W. Li (Eds.), Bilingualism: Beyond basic principles. Clevedon: Multilingual Matters.

Dearing, E., McCartney, K., \& Taylor, B. A. (2009). Does higher quality early child care promote low-income children's math and reading achievement in middle childhood?. Child development, 80(5), 1329-1349.

DeLoach, D. (2012). Effects of a prekindergarten mathematics intervention on mathematical abilities of preschoolers with low socio-economic status. (Unpublished Doctoral Dissertation). Walden University, USA.

Duncan, G., Dowsett, C., Claessens, A., Magnuson, K., Huston, A., Klebanov, P., \& Japel, C. (2007). School readiness and later achievement. Developmental Psychology, 43, 14281446.

Epstein, J. L., Galindo, C. L., \& Sheldon, S. B. (2011). Levels of leadership: Effects of district and school leaders on the quality of school programs of family and community involvement. Educational Administration Quarterly, 47(3), 462-495.

Erdoğan, S. (2006). A study on the effects of mathematics education given with drama method to six years old children mathematics ability (Unpublished Doctoral Dissertation). Ankara University Institute of Science, Ankara.

ERG (2010). Education report 2010. İstanbul: İmak Ofset.

Galindo, C., \& Sheldon, S. B. (2012). School and home connections and children's kindergarten achievement gains: The mediating role of family involvement. Early Childhood Research Quarterly, 27, 90-103.

Ginsburg, H. P., Baroody, A. J. (2003). Test of Early Mathematics Ability Examiner's Manual-Third Edition. Texas: Pro-Ed An International Publishing.

Ginsburg, H. P., Greenes, C. E., \& Balfanz, R. (2003). Big math for little kids: Prekindergarten. Texas: Pearson Learning Group.

Greenes, C., Ginsburg, H. P., \& Balfanz, R. (2004). Big math for little kids. Early Childhood Research Quarterly, 19(1), 159-166.

Halliday, M. A. (1993). Towards a language-based theory of learning. Linguistics and education, 5(2), 93-116. 
Kagitcibasi, C., Sunar, D., \& Bekman, S. (2001). Long-term effects of early intervention: Turkish low-income mothers and children. Journal of Applied Developmental Psychology, 22(4), 333-361.

Koşan, Y. (2015). Okul öncesi eğitimin iki dilli çocukların okula hazır bulunuşluklarına etkisinin incelenmesi [An examination of the impact of early childhood education on bilingual children's school readiness]. (Unpublished Master Dissertation). Hacettepe Üniversitesi Eğitim Bilimleri Enstitüsü.

Klibanoff, R. S., Levine, S. C., Huttenlocher, J., Vasilyeva, M., \& Hedges, L. V. (2006). Preschool children's mathematical knowledge: The effect of teacher" math talk.". Developmental psychology, 42(1), 59.

Lee, J. L., \& Bowen, N. K. (2006). Parental involvement, cultural capital, and the achievement gap among elementary school children. American Educational Research Journal, 43(2), 193-218.

Matthews, H., \& Ewen, D. (2006). Reaching all children? Understanding early care and education participation among immigrant families. Center for Law and Social Policy, Inc. (CLASP).

McLaughlin, B. (2013). Second-language acquisition in childhood. Hillsdale, NJ: Erlbaum

Morgenlander, M., \& Manlapig, L. (2006). Big math for little kids workshops: Background and content. In annual meeting of the American Educational Research Association, San Francisco. Retrieved april (Vol. 22, p. 2014).

Myers-Scotton, C. (2002). Contact linguistics: Bilingual encounters and grammatical outcomes. Oxford: Oxford University Press on Demand.

Opel, A., Zaman, S. S., Khanom, F., \& Aboud, F. E. (2012). Opel, A., Zaman, S. S., Khanom, F., \& Aboud, F. E. (2012). Evaluation of a mathematics program for preprimary children in rural Bangladesh. International Journal of Educational Development, 32(1), 104-110.

Pallant, J. (2015). SPSS Survival Manual. Berkshire: Open University Press.

Presser, A. L., Clements, M., Ginsburg, H., \& Ertle, B. (2012). Effects of a preschool and kindergarten mathematics curriculum: Big Math for Little Kids. Center for Children and Technology. Retrieved from: http://cct. edc. org/publications/effects-preschoolandkindergarten-mathematics-curriculum-big-math-little-kids-final. 104-110.

Presser, A. L., Clements, M., Ginsburg, H., \& Ertle, B. (2012). Effects of a preschool and kindergarten mathematics curriculum: Big Math for Little Kids. Center for Children and Technology. Retrieved from: http://cct. edc. org/publications/effects-preschoolandkindergarten-mathematics-curriculum-big-math-little-kids-final.

Skwarchuk, S. L. (2009). How do parents support preschoolers' numeracy learning experiences at home?. Early Childhood Education Journal, 37(3), 189-197.

Tseng, C. H. (2002). An overview on peripheral vascular disease in blackfoot diseasehyperendemic villages in Taiwan. Angiology, 53(5), 529-537.

TUİK (2015). Türkiye İstatistik Kurumu verileri [Turkey Statistical Institute data]. Erişim adresi: http://www.tuik.gov.tr.

Unutkan, P. Ö. (2006). Okul öncesinde ilköğretime hazırlık [Preparation for primary education before school]. İstanbul: Morpa Yayınları.

Uyanık, Ö. ve Kandır, A. (2010). Okul öncesinde erken akademik beceriler [Early Academic Skills in Preschool Period]. Kuramsal Eğitimbilim, 3(2), 118-134.

Watson, C. (1996). Helping families from other cultures decide on how to talk to their child with language delays. Wig-Wag: The Newsletter for Hanen Certified SpeechLanguage Pathologists and Therapists [On. Available: http://www/hanen.org/Onetwo.html. 
Whitin, P. (1996). Sketching Stories, Stretching Minds: Responding Visually to Literature. Heinemann: NH 03801-3912.

Williams, D., \& Coles, L. (2007). Teachers' approaches to finding and using research evidence: An information literacy perspective. Educational Research, 49, 185206.

Yazgan, Y. (2015, 26 August). İki dillilik [Bilingualism]. Retrieved from: http://www.yankiyazgan.com/iki-dillilik/

Yoder, P. J., \& Warren, S. F. (1998). Maternal responsivity predicts the prelinguistic communication intervention that facilitates generalized intentional communication. Journal of Speech, Language, and Hearing Research, 41(5), 12071219.

Young-Loveridge, J. M. (2004). Effects on early numeracy of a program using number books and games. Early Childhood Research Quarterly, 19(1), 82-98. 